\title{
Possible applications and potentials for LNG (Liquefied Natural Gas) in Central Europe
}

\author{
Laura SIMMER ${ }^{1, a^{*}}$, Sarah PFOSER ${ }^{2, b}$, Gerald ASCHAUER ${ }^{3, c}$ \\ and Oliver SCHAUER ${ }^{4, d}$ \\ 1,2,3,4 University of Applied Sciences Upper Austria, Wehrgrabengasse 1-3, 4400 Steyr, Austria \\ alaura.simmer@fh-steyr.at, 'barah.pfoser@fh-steyr.at, 'cgerald.aschauer@fh-steyr.at, \\ doliver.schauer@fh-steyr.at
}

Keywords: Liquefied Natural Gas, LNG, energy supply, alternative fuel

\begin{abstract}
In the current discussion about alternative energy supply and strategies in Europe, LNG comes to the fore. For the implementation of LNG in Central Europe, there are many hurdles to be overcome. With the "LNG Masterplan Rhine-Main-Danube", a first step is being made to overcome these barriers. Within this Masterplan, a Framework and Market Analysis was conducted. Therefore, extensive literature research was carried out in a first step, to have a detailed analysis and assessment of the developments for the implementation and applications of LNG. The results of this paper should not only point to the problem areas, but to the potentials for LNG as well and make a significant contribution for further implementation steps.
\end{abstract}

\section{Introduction}

Due to the rising global demand for natural gas, an increased competition in the gas markets is expected. This increased competition is one of the major challenges of the European gas industry in the coming decades [1], whereby LNG becomes an important topic in the discussion and debate about alternative energy supply strategies. LNG provides independence of pipelines and can therefore contribute to the diversification of supply sources and help to avoid one-sided dependencies. New, previously unattainable sources can be developed. Thus, the flexibility in the energy supply will increase. Internationally, there is already diverse and extensive experience in dealing with LNG. Today the LNG share in the global gas trading is at about $30 \%$, in Europe at only $15.5 \%$ [2]. In the EU, mainly the following countries are established in the LNG business: Spain, Britain, Italy and France. Many obstacles must be overcome in order to establish LNG also in Central Europe; however, LNG has some advantages. New perspectives arise in the energy transport system, because LNG provides independence of pipelines and can thus contribute to the diversification of supply sources. As the European transport-sector has a $96 \%$ oil dependency and transport accounts for around a third of the final energy consumption and for more than a fifth of EU greenhouse gas emissions in 2011 [3], drivers for the use of LNG as fuel are, on the one hand, the independence of oil and lower fuel costs; on the other hand, LNG wins importance by increasingly stringent emission regulations. This applies both to the inland waterways as well as to heavy traffic. Compared to diesel, the use of $\mathrm{LNG}$ reduces $\mathrm{SO}_{\mathrm{X}}$ emissions and particulate matter by almost $100 \%, \mathrm{NO}_{\mathrm{X}}$ emissions by $80-90 \%$ and $\mathrm{CO}_{2}$ emissions by almost $20 \%$ [4]. For these reasons the European Commission made a proposal for a Directive on the deployment of alternative fuels infrastructure, including LNG. Within the framework of the TEN-T Call 2012, seven LNG projects receive financial support. One project is the "LNG Masterplan for the Rhine-MainDanube". The project will provide a European strategy and pilot deployments for LNG as fuel for inland vessels as well as for LNG as cargo being transported on waterways and distributed via inland ports. The action consists of a set of feasibility studies, technical concepts, technical trials and pilot deployments of vessels and terminals [5]. 


\section{Materials and experimental procedure}

As the "LNG Masterplan Rhine-Main-Danube" consists of six work packages, and the first one is a framework and market analysis, the aim of this work is a detailed analysis and assessment of the developments for the implementation and applications of LNG in Central Europe. For this purpose, an extensive literature search was carried out in a first step. Further research comprises the assessment of different supply chain scenarios and an initial demand survey along the Rhine-MainDanube axis in Central Europe.

\section{Results and Discussions}

\section{Challenges and opportunities for the introduction of LNG in Central Europe}

In the EU, mainly the countries of Spain, Britain, Italy and France are established in the LNG business. Once LNG has arrived at the LNG import terminal, the liquid natural gas is usually regasified to normal natural gas and fed into the gas grids. For the use of LNG in Central Europe so called "small scale" LNG projects are in focus. These include small liquefaction plants, the LNG trans-shipment of large vessels to smaller vessels and trucks, the storage of LNG in satellite stations and the use of LNG as a fuel [6]. In contrast to the large scale LNG market, the small scale LNG market is still new. Thus the situation in Central Europe can be characterized as the often quoted chicken-and-egg problem. On the one hand, potential customers do not show any demand because there is no infrastructure for using LNG. On the other hand, necessary infrastructure won't be provided if there is no sign of demand. However in some regions of Europe, the required infrastructure already exists. But rather than the spread of infrastructure another issue to overcome is how to supply the regions of Central Europe with LNG.

Supply:

There are two possibilities for LNG supply: (i) to buy it at LNG terminals or (ii) to liquefy pipeline natural gas directly onsite. Concerning the way how LNG is distributed after buying it at an import terminal, there are three possibilities. First, it can be reloaded to specific containers or tank trucks and then be transported by truck. This truck loading is possible at LNG terminals in Belgium, the Netherlands, France, Portugal and Spain. Some other terminals, e.g. in Italy, are currently discussing this possibility [7]. However, truck transports are environmentally and economically only feasible for limited distances. The second option is to transport LNG on inland waterways. In contrast to road transports, this is a very sustainable way of moving LNG. There are two problems with this option: (i) the European Agreement concerning the International Carriage of Dangerous Goods by Inland Waterways (ADN) currently forbids the transport of LNG via inland waterway tankers and (ii) no LNG inland tanker already exists [8,9]. Within the LNG Masterplan RhineMain-Danube these problems should be solved and therefore three LNG inland tankers are under construction [10]. It is also important that the import terminals offer the loading possibilities for these small tankers. Finally, the last option to distribute LNG to Central Europe is by train. This mode of transport is mainly used in Japan [11]. Here LNG can be reloaded to specific rail tank cars or in ISO containers. Currently no rail tank cars exist in Europe, but VTG and Chart Ferox will build two prototype units for the carriage of LNG by rail [12]. Unfortunately, no European import terminal offers rail loading at the moment [7], so for now the only possibility to bring LNG to Central Europe is to fill up an ISO container and bring it by truck to the next railway station.

Regarding the second option, a very different way of obtaining LNG is to produce it from pipeline gas. As the pipeline network is wide spread in Central Europe, LNG can be available where there is a request. The main issue of this option concerns the availability of small-scale liquefaction plants and the necessity to find the right trade-off between capital costs and energy efficiency for plants at this scale [13]. 


\section{Applications and Demand:}

LNG can be used for various different purposes in industry, but also as fuel for ship, as well as for heavy transport. LNG usage in the industrial sector will only pay off in areas where there is no gas pipeline access, for example in Norway, where fjords and mountains cut companies partly off gas grids. Especially in Austria most companies have sufficient energy provision as a result of excellent access to various forms of energy. Therefore, the potential of LNG in Central Europe is more in the use of LNG as fuel as for industrial purposes.

In Europe more than 200 heavy duty vehicles use LNG as fuel, and there are about 40 LNG stations in operation [14]. Most of these stations are in Britain (13 LNG refueling stations) followed by Spain (12 LNG refueling stations), Sweden (8 LNG refueling stations) and the Netherlands (7 LNG refueling stations). In Central Europa (Austria, Germany, Poland, Czech Republic, Slovakia, Hungary and Slovenia) there is just one LNG station in Poland [15]. Besides the lack of gas stations, low acceptance or ignorance of consumers and the high price of vehicles preclude the introduction [16]. However, the cost of a truck could be reduced with a roll-out of infrastructure and acceptance of LNG as the preferred fuel. Currently, a new LNG truck is still around 45,000-55,000 € more expensive compared to a diesel truck. These additional costs are explained by higher material costs, higher security requirements and a low production number. Retrofitting a diesel truck costs at least 15,000-20,000 €, mainly due to the expensive LNG tank [17].

LNG has served as a marine fuel for many years, but primarily on LNG carriers as "the boil off" gas. It was utilized in marine boilers or dual fuel engines. It is only within the last decade that the LNG powered ship market has grown in Europe [18]. More than 25 vessels use LNG as their main fuel now. Most of these vessels are in operation in Norway [19]. This growth is mainly due to stringent environmental regulations in coastal areas. For inland vessels, LNG as a fuel is currently still banned in Europe. Nevertheless, there are already three successful examples of barges, which operate with a certification of exemption between Basel and Rotterdam [4]. In order to promote the topic LNG professionally, placing it politically and underpinning it legally, there are many ongoing projects and activities.

\section{Pilots and best practice:}

\section{LNG as ship fuel:}

One of these projects is the "North European LNG Infrastructure Project" of the Danish Maritime Authority, together with 14 partners. The project is part of the "Trans-European Transport Network (Ten-T) program" and the main purpose of this project is recommendations for the establishment of an infrastructure for the use of LNG as a marine fuel. The recommendations are aimed at the problems in the development of such an infrastructure, the necessary measures to resolve these problems and the main actors that can contribute to overcome these problems [20,21,22].

Another project is the "Clean North Sea Shipping project", under the "North Sea Region Programme", which includes 18 partners from six different countries. The Hordaland County Council took over the project management. The goal is to improve the environmental and health situation caused by air pollution and greenhouse gases due to shipping. A study will include the LNG supply chain, bunker procedure, legal framework, security issues, environmental impacts, cost-benefit analyses, market and trend analyses, stakeholder requirements, project examples, scenarios and emission modelling and policy and strategy developments [23, 24].

Further projects are the "Clean Baltic Sea Shipping project", the "ITRANSFER project (Innovative Transport Solutions for Fjords, Estuaries and Rivers)" and the "Martech project (Marine Competence, Technology and Knowledge)".

As these projects are all along the coastal countries, the LNG Masterplan is the first project to bring LNG in landlocked Europe and break the chicken and egg situation. Connecting a large number of sea and inland ports along this important waterway with pioneer industry partners will 
enable the coordinated action and critical mass necessary to make a change: 33 companies along with the relevant authorities from 12 countries will create the critical mass of stakeholders needed for the development. The LNG Masterplan therefore, shall pave the way for a full scaledevelopment of LNG as a fuel and cargo on the European inland waterways in the forthcoming next decade [25].

\section{LNG as truck fuel:}

Despite many barriers there are successful pilot applications in Europe. One is the use of LNG in the municipal transport buses from Krakow. The problem of exhaust gas emissions is especially acute in Krakow. To enable an improvement in living standards, the VTC (Vehicle Transport Company) has purchased 15 articulated buses SM18 LNG and 16 standard buses SM12 LNG. The buses were supplied by the Polish company Solbus and equipped with Cummins engines from the USA. The construction of the LNG refueling station was built by the company KRI SA [26].

Another example is the LNG refueling station in the Netherlands, opened in 2010 by Vos Logistics together with Mercedes-Benz Netherlands, LNG Europe, Van Ganswinkel and Indox CryoEnergy Spain. Vos Logistics owns already 14 LNG trucks, further 50 to 100 should follow [27].

In Germany LNG vehicles were subjected a four-week practical test by the company Hellmann Worldwide Logistics. Now, the first LNG vehicles are ordered and a permit for the building of a gas station is also available [28].

The "LNG Blue Corridor Project" is an EU project funded with eight million euro (Call: FP7TRANSPORT -2012- MOVE -1), which aims to improve the knowledge and awareness of LNG as alternative fuel for the medium and long distance road transport. The core of the project consists of four corridors (West-East, South-North, Atlantic and Mediterranean), along 14 new LNG or LCNG stations should be set up in order to operate about 100 trucks $[29,30]$.

The "BiMe (Liquid biomethane and methane diesel technology in trucks)" was a national LNG corridor project in Sweden, which expired at the end of 2013. The aim of this project was $100 \mathrm{LNG}$ powered heavy long haul vehicles and the construction of at least three gas stations (Gothenburg, Stockholm, Malmo) [31, 32].

In 2011, under the name "Green Deal", the Dutch government launched a program of cooperation between industry and government to achieve emission targets. More than 150 so-called "Green Deals" were signed. One of these is the Green Deal "Rhine and the Wadden Sea". Aims of this project are 50 LNG inland- and 50 sea-going vessels and 500 LNG powered trucks by 2015 [33, 34].

As all these projects take place outside Central Europe, here may be even more potential.

\section{Conclusions}

LNG will globalize the gas market and create flexibility in the transportation of natural gas. If Central Europe wants to benefit from this development, the infrastructure in all areas of the supply chain must be established. This requires actions in various fields, so the topic LNG continues to provide sufficient space for research and implementation projects and a number of open issues must be clarified in the future. It is important to define unified and regulatory frameworks and safety standards for the handling of LNG. Flexibility, independent sourcing, price advantages, alternative export markets but also new emission control regulations make LNG an increasingly attractive energy and fuel option and the use of LNG could be an important decision for further research into the use of and on the transition to hydrogen. 


\section{References}

[1] R. Hinterberger, Visions- und Strategiepapier für ein Smart Gas Grid, information on: http://download.nachhaltigwirtschaften.at/edz_pdf/1157b_visionspapier.pdf, accessed: 2014-07-04.

[2] BP, BP Energy Outlook 2030, information on: http://www.bp.com/content/dam/bp/pdf/statistical-

review/BP_World_Energy_Outlook_booklet_2013.pdf, accessed: 2014-07-04.

[3] European Environment Agency (EEA), Transport, information on: http://www.eea.europa.eu/themes/transport/intro, accessed: 2014-07-04.

[4] S. Kumar, H. Kwon, K. Choi, W. Lim, J.H. Cho, K. Tak, I. Moon, LNG: An eco-friendly cryogenic fuel for sustainable development, Applied Energy, 88 (2011) 4264-4273.

[5] M. Seitz, LNG as fuel for inland vessels and as a cargo on the rhine-main-danube, Small Scale LNG Forum, Rotterdam, 2013.

[6] F.I. Nogueras, LNG Trucking: A First Step to the Development of LNG for Fuel for Transportation, Small Scale LNG Forum, Rotterdam, 2013.

[7] Gas LNG Europe, Small scale LNG map, version March 2014.

[8] European Maritime Safety Agency (EMSA), Study on standards and rules for bunkering of gasfuelled ships, Germany, 2013.

[9] J. Schweighofer, Application of LNG as fuel for Danube navigation, presentation, New Orleans, 2011.

[10] M. Seitz, LNG Masterplan for Rhine - Main - Danube, presentation, Budapest, 2013.

[11] U. Fahl, M. Härdtlein, E.D. Özdemir, S. Rath-Nagel, U. Remme, L. Eltrop, Möglichkeiten der LNG-Nutzung in Baden-Württemberg, study, IER University of Stuttgart, 2009.

[12] M. Gabler, M. Votapkova, Rail innovation: VTG and Chart Ferox build rail tank cars for the transport of liquid natural gas ("LNG"), information on: http://www.vtg.com/v/s/content/1560/202682;jsessionid=D0009898A3C0F7474A71AD1CCFC47F DA, accessed: 2014-07-04.

[13] A. Arteconi, F. Polonara, LNG as vehicle fuel and the problem of supply: The Italian case study, Energy Policy 62 (2013) 503-512.

[14] M. Lage, The use of Natural Gas in the transportation Industry, information on: http://www.apvgn.pt/documentacao/lage_agn_out12.pdf, accessed: 2014-07-04.

[15] J. Del Álamo, NGVs \& refuelling stations in Europe, Natural Gas Vehicle Association, 2013.

[16] Amt für Veröffentlichungen, Arbeitsunterlage der Kommissionsdienststellen Zusammenfassung der Folgenabschätzung: Begleitunterlage zum Vorschlag für eine Richtlinie über den Aufbau der Infrastruktur für alternative Kraftstoffe /* SWD/2013/06 final */.

[17] PwC, The economic impact of small scale LNG, information on: http://www.nationaallngplatform.nl/wp-content/uploads/PwC-Economic-impact-of-small-scale-

LNG_STC.pdf, accessed: 2014-07-04.

[18] J. Herdzik, LNG as a Marine Fuel - Possibilities and Problems, information on: http://ilot.edu.pl/kones/2011/2_2011/2011_herdzik_lng_as_a_marine_fuel.pdf, accessed: 2014-0704.

[19] J. Robin, V. Demoury, The LNG Industry in 2012, information on: http://www.giignl.org/sites/default/files/publication/giignl_the_lng_industry_2012.pdf, accessed: 2014-07-04.

[20] B. Forsman, North European LNG Infrastructure Project: Appendix J Safety Aspects/Risk Assessment. A feasibility study for an LNG filling station infrastructure and test of recommendations, information

on: http://www.dma.dk/themes/LNGinfrastructureproject/Documents/Documents/LNG_draft_FR_2011 1128_app_J.pdf, accessed: 2014-07-04. 
[21] J. Gahnström, E. Molitor, North European LNG Infrastructure Project: Appendix G Port and Terminal Aspects on LNG Bunkering. A feasibility study for an LNG filling station infrastructure and test of recommendations, information http://www.dma.dk/themes/LNGinfrastructureproject/Documents/Documents/LNG_draft_FR_2011 1121_app_G.pdf, accessed: 2014-07-04.

[22] Danish Maritime Authority, North European LNG Infrastructure Project. A feasibility study for an LNG filling station infrastructure and test of recommendations, information on: http://www.dma.dk/themes/LNGinfrastructureproject/Documents/Final\%20Report/LNG_Full_repor t_Mgg_2012_04_02_1.pdf, accessed: 2014-07-04.

[23] Clean North Sea Shipping (CNSS), A review of present technological solutions for clean shipping, information on: http://cnss.no/wp-content/uploads/2011/10/Summary-brochure10.pdf, accessed: 2014-07-04.

[24] Clean North Sea Shipping (CNSS), LNG fuelled ships as a contribution to clean air in harbours. CNSS Work package 4, Showcase LNG, information on: http://cnss.no/wpcontent/uploads/2013/08/CNSS-LNG-report-4mb.pdf, accessed: 2014-07-04.

[25] O. Schauer, L.M. Putz, F. Starkl, The European LNG Masterplan: Introducing LNG as fuel and cargo on the Rhine-Main-Danube, Proceedings of the 8th International Symposium on Environmentally Conscious Design and Inverse Manufacturing: ECODESIGN 2013, Jeju Island, Südkorea, 2013.

[26] G. Cebrat, C. Anacker, Documentation and Evaluation of International Case Studies, Compiled within the European research project, Deriving effective least-cost policy strategies for alternative, Forschungsgesellschaft Mobilität - Austrian Mobility Research, 2010.

[27] F. Verhoeven, Vos Logistics strengthens sustainable transport fleet by introducing LNG trucks for regional distribution, information http://www.voslogistics.com/News\%20and\%20Information/News/Vos\%20Logistics\%20strengthen s\%20sustainable $\% 20$ transport $\% 20$ fleet $\% 20$ by $\% 20$ introducing $\% 20 L N G \% 20$ trucks $\% 20$ for $\% 20$ regio nal\%20distribution/\$id3494, accessed: 2014-07-04.

[28] D. Huelemeyer, Alternative Antriebskonzepte - Feldversuch Liquid Natural Gas (LNG), information on: http://www.wirtschaft-pro-klima.de/default.asp?Menue=597\&Firma=2802013, accessed: 2014-07-04.

[29] T. Denys, Alternative fuels for road transport, Workshop: Mobility: Technology Priorities and Strategic Urban Planning, Finnland, 2013.

[30] LNG Blue Corridors, information on: http://www.lngbluecorridors.eu/, accessed: 2014-04-07.

[31] H. Larsson, BiMe Trucks, Developing the Uptake of Liquid Biomethane in Heavy Duty Transport, Global Biomethane Conference, Brüssel, 2012.

[32] Y. Persson, Corridor of liquefied biomethane for road transports, Final Conference Scandria, Malmö, Schweden, 2012.

[33] Rotterdam Climate Initiative, Introduction of LNG as transport fuel will generate billions of euros and thousands of jobs, information on: http://www.rotterdamclimateinitiative.nl/en/english2011-design/news?news_id=1154, accessed: 2014-07-04.

[34] P. Kager, Small Scale LNG, Current State of Play in Europe and Outlook for the next Decade, information on: http://www.gie.eu/conference/presented/2013/S4_03_Gasunie_PKager.pdf, accessed: 2014-07-04. 